\title{
The Roles of Social Status, Age, Gender, Familiarity, and Situation in Being Polite for Bugis Society
}

\author{
Murni Mahmud ${ }^{1}$ \\ ${ }^{1}$ Faculty of Languages and Literature, State University of Makassar, Indonesia \\ Correspondence: Murni Mahmud, Faculty of Languages and Literature, State University of Makassar, Indonesia. \\ E-mail: dwimurnye@yahoo.com
}

Received: February 6, 2013

Accepted: March 6, 2013 Online Published: April 27, 2013

doi:10.5539/ass.v9n5p58

URL: http://dx.doi.org/10.5539/ass.v9n5p58

\begin{abstract}
This paper examines the important roles of social status, age, gender, familiarity, and situation in being polite for Bugis people. This paper is based on my study on politeness in Bugis society, conducted in 2005 in two different Bugis communities in South Sulawesi: the first was in Awangpone, a rural area a few kilometres north of the regional peninsula of South Sulawesi; the second was in Parepare, the second city of the province located on the west coast, about $155 \mathrm{~km}$ north of Makassar. The result of the research shows that the choice of being polite for Bugis people is influenced by differences in social status, age, gender, familiarity, and situation. In both areas of the study, there is a different practice of being polite influenced by those above factors. In rural area, social status differences become the most important factor whereas in urban area, gender differences can become the higher priority in encoding their politeness.
\end{abstract}

Keywords: politeness, social status, age, gender, familiarity, situation, Bugis society

\section{Introduction}

There have been a lot of studies in politeness since Brown and Levinson (1987) proposed theories on politeness strategies. Studies have been conducted to explore politeness practices in particular society, for example in China (Gu, 1990; Zhan, 1992), Thailand (Kummer, 1992; Intachara, 2011), and Japan (Pizziconi, 2003). Studies on politeness have also been conducted in many different contexts such as in politics and legal system (Kakane, 2008; Shibamoto-Smith, 2011) and in education (Bacha, Bahous \& Diab, 2012).

In Indonesia, the study of politeness was pioneered by Geertz (1960), who refers to politeness as 'etiquette' in Javanese society. Wouk (2001) has examined the use of the discourse marker $y a$ 'yes' to maintain solidarity in Indonesian. Buchori (1994:77) has also studied politeness in Indonesia and stated that politeness is 'a traditional code of behaviour through which individuals show their mutual respect for each other'. Studies have also been conducted on the relationship between Javanese speech styles and social status (Geertz, 1960; Kartomiharjo, 1981; Errington, 1985, 1986, 1988, 1998; Berman, 1998). The Sasak language in Lombok has also been analysed in this way (Mahyuni, 2004), emphasizing the use of Sasak language with reference to social status: menak/ non-menak in the local community. However, few of these linguistically specific studies in Indonesia have discussed the relationship between language use, particularly politeness, and gender roles. Berman's study (1998) on Javanese speech styles in Yogyakarta, for example, concentrated on Javanese narrative styles with reference to gender differences, but did not specifically look at politeness issues in relation to gender roles in Java.

Bugis society, as an important ethnic group in South Sulawesi, Indonesia has also interesting cultural and social system.There is a long history of linguistic and cultural studies of the Bugis by both Indonesian and foreign scholars such as the recent studies of status (Abdullah, 1985; Millar, 1983, 1989; Brawn, 1993; Pelras, 1996; Idrus, 2003) and gender issues (Millar, 1983, 1989; Graham, 2001; Idrus, 2003, 2005, 2011; Alimi, 2012). Millar (1989), for example, investigated gender in relation to Bugis weddings in Soppeng, South Sulawesi. A specific study in Bone, one of the sites for my fieldwork, has been conducted by Brawn (1993), who examined the ways of living in Bone in relation to social status. A study has been conducted by Idrus (2003) concerning gender, sexuality, and marriage in one of the Bugis communities, Sidrap. 
This paper is going to examine the politeness practices of Bugis people influenced by aspects such as age, social status, gender, familiarity, and situation. The discussion of politeness in this paper is mainly based on Brown and Levinson theory which considers a number of variables which might affect the level of politeness, such as 'power, distance, and rank of imposition' (1987:74). Other aspects in communication have important roles in determining the level of politeness such as differences in social status, age, gender, familiarity, and situation.

\section{Materials Studied}

\subsection{Politeness}

Analysing politeness is complex. One of the reasons is that there is a difference between what is expected in a particular society and what happens in real life. Graham (2007:743) states that 'perception of (im)politeness vary from one individual to one another and there are multiple gradations of more- or less- (im)polite behaviour'.

Therefore, it cannot be denied that politeness needs to be examined in a social context. Brown and Levinson (1987:74) consider a number of variables which might affect the level of politeness, such as power, distance, and rank of imposition whereas according to Holmes (1995), there are three dimensions which have proved useful in analysing linguistic politeness, namely 'solidarity-social distance dimension', the 'power dimension', and the 'formality dimension'.

Therefore, power relations are important in politeness. According to Brown and Levinson (1987:77), power is 'the ability of one person to impose their will on another' whereas according to Holmes (1995:17), the power dimension refers to the ability of the participants to influence one another's circumstances. Therefore, one person may be said to have power over another to the degree that he or she is able to control the behaviour of the other. Power is a relationship between at least two persons, and it is nonreciprocal in the sense that both cannot have power in the same area of behaviour.

One of the factors influencing power differences is the age differences. Conversations between people of different ages frequently show different level of politeness. Mizutani and Mizutani (1987:4) affirm that differences in age will influence the formality of speakers and hence the degree of politeness. It has become a rule in Japan that older people talk in a familiar way toward younger people, and younger people talk politely to older people. In contrast, people of the same age commonly use familiar speech styles in conversation.

Another aspect of power is the notion of status, which is derived from the Latin term for 'standing' and relates simply to one's position in society, conferring 'rights and obligations upon a person as a citizen within a political community' (Turner, 1988:2). According to Bonvillain (1993:145-146), status differences may be based on 'combinations of income, occupation, education, and resulting differences in access to social, economic, and/or political power and this reflect inequalities among sectors of a population'.

Such aspects of power relations determine the low or high level of conversations. Brown and Levinson's idea in this case is that 'the more powerful a person, the more influential he is in the conversations'. His level of politeness may even decrease to less polite speech. Hung and Bradac (1993:37) state that 'Polite language may be seen as deferential and indicative of low status in some situations but as effective and indicative of high status in others.'

Another factor relating to differences in communicative styles is gender, based on the idea that men and women are different in their language. One of the differences is that women are said to be more polite than men. According to Speer (2002:347), women have a higher tendency than men to apply politeness strategies in their speech such as the use of more compliments, more apologies, and more thanks. Hobbs (2003:243) notes that when talking with same sex peers, women will use many positive politeness strategies. On the other hand, men in similar circumstances do not show this tendency.

Beside the above factors, being familiar between the interlocutors will influence the ways to be polite. Brown and Levinson (1987:74) called this 'social distance' and referred it as 'the degree based on stable social attributes the reflex of social closeness'. This suggests that how familiar speakers are with each other will determine how politely they behave. The closer they are, the less polite they need to be.

Situation or speech situation, either formal or informal, is also an influential factor in communication. Normally, people talking in formal situations will use more polite speech whereas in informal situations, speakers tend to use a more familiar style of speech. In addition, people also change levels of speech depending on the situation, even when talking with the same person. Holmes (1995:17) refers to this as the 'formality dimension', which concerns the situational factors that influence people to be polite or not. She further states that 'context is a fundamental 


\subsection{Bugis Society}

Bugis society which becomes the subject of this research is rich in terms of social system

such as Bugis social status, the roles of age superiority or age differences, and gender roles. According to Pelras (1998:25), 'Bugis society is one of the most complex and apparently rigidly hierarchical of any in the archipelago, with distinct strata comprising several degrees of mobility'. In Bugis society, the hierarchical system can be traced by looking at social status, referred to as onrong, onro, and a'batireng, which all mean 'place' or 'social status'. Pelras (1996:334) also notes that in the Bugis society of today, there are four main types of status: the to-sugi' 'the wealthy, successful entrepreneurs'; the to-warani 'military'; the to-acca 'the holders of academic diplomas'; and the to-panrita 'the Islamic masters'.

The accumulation of status in Bugis is an example of Ossowski's (1963, p.49) observation that 'social status is determined by several factors, and that, within certain limits at least, these factors may compensate for one another'. This creates a 'synthetic gradation' of status. In addition, this can become a means to gain honour in the forms of 'the privilege of wearing special costumes, of eating special dishes taboo to others, of carrying arms, the right to pursue certain non-professional dilettante artistic practices, e.g. to play certain musical instruments' (Weber cited in Gerth and Mills, 1976:190-191).

Millar (1983:479-480) also notes that Bugis society recognises a hierarchy determined by age. Bugis acknowledge the age differences in society, and have the notion of to-matoa 'the eldest'. These people may be as young as 25 , but should have 'valued aspects of age' such as high fated bateng 'inner condition' amplitude; lahireng 'socially manifest behaviour and accomplishments'; and exhibit the quality of malebbi' 'a noble excellence' and authority.

The third important aspect of the Bugis social system is the role of gender, which has been one of the main topics for investigation by some scholars. Pelras (1996:163) notes that the flexibility of Bugis behavioural gender distinctions is well expressed in the saying 'whoever, although a man, has female qualities, is a woman; and although a woman, has male qualities, is a man. This shows that the Bugis have strong expectations about men and women's roles in society. According to Millar (1983:163), gender relations are reflected in a Bugis saying that the woman's domain is around the house while the man's domain reaches 'the borders of the sky'. This formulation defines the respective roles of man and woman in domestic life, where the man is the main provider of income while the woman is occupied mainly in the house or not too far from it and is the main income spender.

\section{Area Descriptions}

My fieldwork was conducted in two different Bugis locations, Bone and Parepare (see Figures 1 and 2). I chose to concentrate on Bone and contrast the situation in this rural area with that in Parepare, the principal Bugis city, where I expected to observe speakers of varying dialects, in often impersonal urban settings.

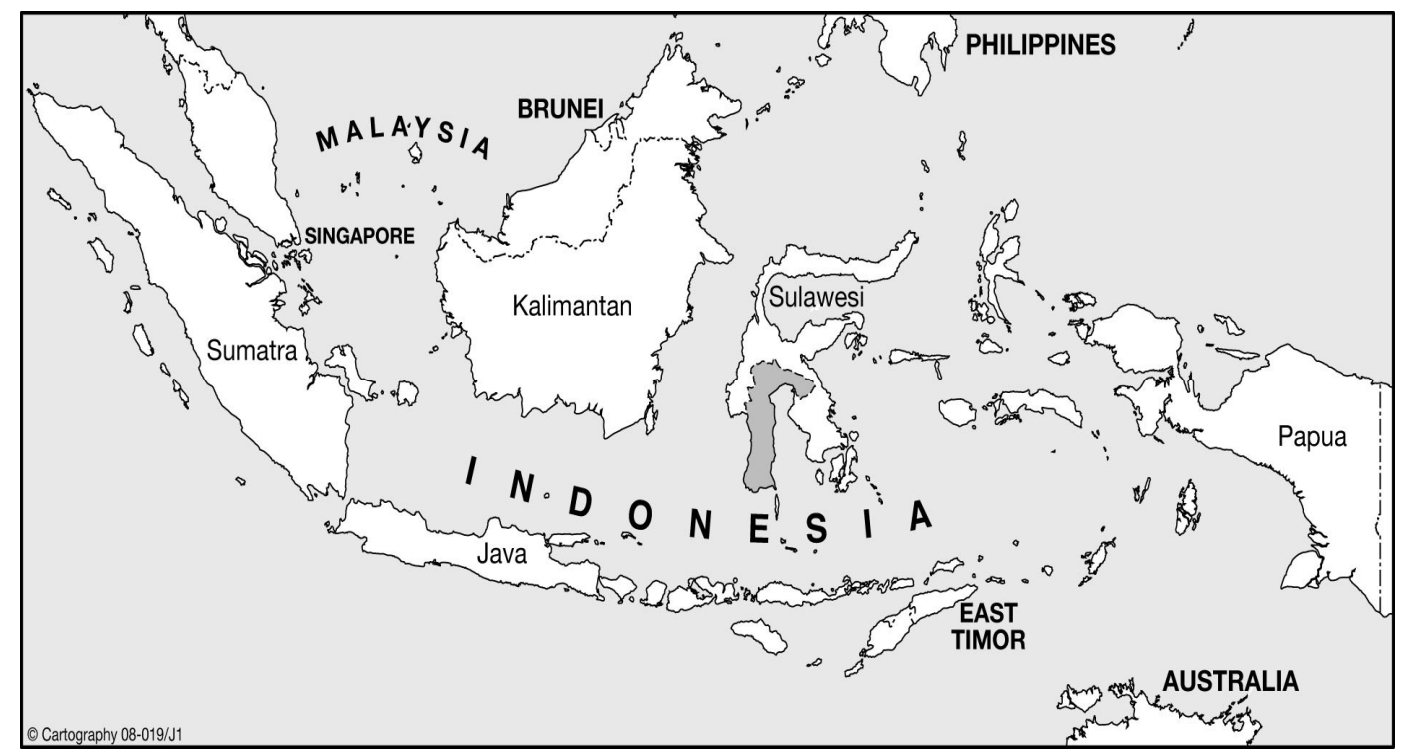

Figure 1. Indonesia, indicating South Sulawesi 


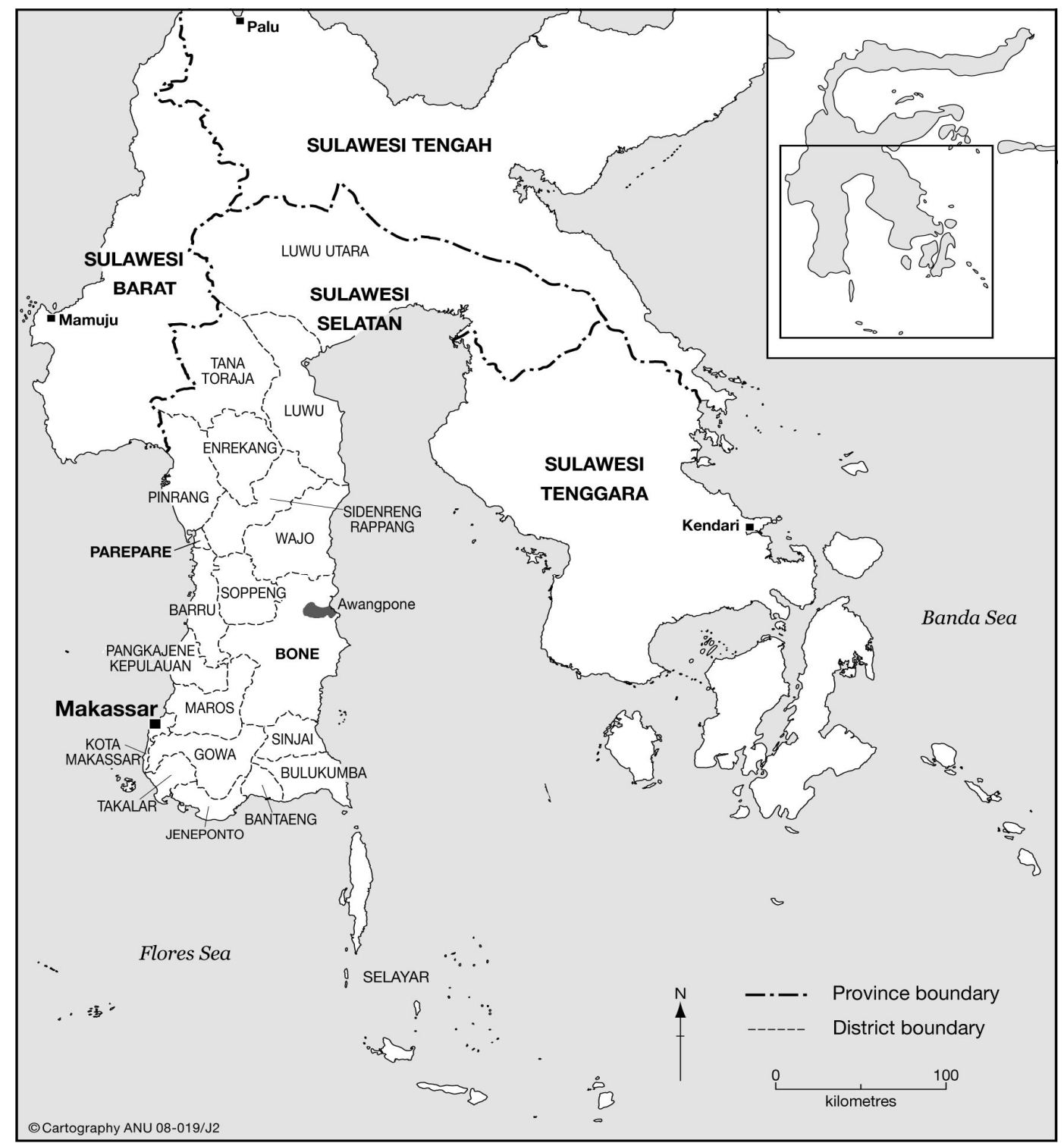

Figure 2. South Sulawesi, indicating fieldsites

\section{Methods}

To collect data, I employed ethnography of communication using some strategies such as participant observation, informal interview, and recording conversations. I interviewed and observed the local people to understand their concepts of politeness. Interviews were conducted with adat 'culture leaders,' religious leaders, and professional workers aged from 23 to 73 years old, both men and women in different contexts to compare the theoretical concept of politeness with the local perspectives of people. To obtain spoken Bugis language, I recorded a variety of conversations between men and women using tape recorders in formal settings such as in offices and schools and in informal settings such as in families and neighborhood. Participants included housewives, graduate students, office workers, teachers ranging from 15 to 50 years old.

\section{Results}

This part illustrates some extracts of conversations between informants that I recorded in two different Bugis communities. (Note 1) The influence of familiarity, differences in age and social status on either symmetrical or asymmetrical relations among speakers can be seen in the extracts below in the conversations of Aslinah (A, 30) (Note 2) with several interlocutors: 


\section{Extract 1: Aslinah and her younger brother (Note 3)}

Aslinah was asking her younger brother, Adil (Ad, 25) to buy some crepe paper but he did not know what she meant. Aslinah wanted to show him an example to help him understand.

A: (asking his brother to buy something) dé misseng melliakka' anu Ndi'? kertas krep!

'don't you know how to buy that for me, $N d i$ '? crepe paper?'

Ad: aga diaseng?

'what kind of paper?'

A: yétu diébbu' bunga-bunga. Pakkurohé. Walakkoconto

'the one that is used to make flowers. Like that. I will give you an example'

When responding to her brother's question, Aslinah pointed to an example of crepe paper. She was using the familiar pronoun -koin walakko conto 'I will give you an example'. This is influenced by many factors. Besides the informality of the situation, Aslinah's familiar speech was influenced by her older age and the fact that they are siblings. Compare this with extract 2 below when she was talking to her husband $(\mathrm{S}, 36)$ at home:

\section{Extract 2: Aslinah and her husband}

A: jadi, wenni' disikolaé, nappaki'ménré'?

'so, yesterday at school, we [i.e. you] had just gone [to Bone], hadn't we [i.e. you]?'

S: aga?

'what?'

A: di- di Bone?

'in- in Bone?'

S: silalokku' ménré' Bone muengka

'I had just gone to Bone when you arrived'

A: maipaé' dé' talokka jempu'ka'

'why didn't we [i.e. you] come to pick me up instead?'

S: awissengngi? Wasengngi lokkako bolana I Nu', pa'ka acarana

'how did I know? I thought you went to Nu's house, because she had a party'

Pak Sulfikar is older than his wife, but Aslinah also can claim higher status than him as a teacher and a graduate from university. However, she mostly used formal expressions with her husband, that is the use of the first plural pronoun $-k i$ ' and $t a$ - as seen in her expressions: nappaki' 'we [i.e. you] had just' and dé 'talokka 'why didn't we [i.e. you] come'. She could instead say nappako and dé'mulokka, which would be less formal and more familiar and tends to be less polite and less distant. Conversely, her husband just used very familiar pronouns $m u$ - in

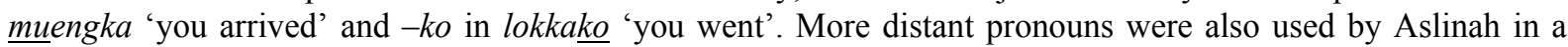
formal setting, in the school such as seen in the following extracts:

\section{Extract 3: The school party}

Aslinah was speaking to her female colleague, Minah (M, 30). They are both similar in age and are both working in a school in Awangpone, although Minah has noble background. At the time, the two teachers were organizing a party for their school. They needed to buy some food for the party, and Minah was going to Bone. Aslinah made an indirect request to Minah to buy some cakes in the market.

A: aga lo'taelli?

'what are we [i.e. you] going to buy?'

M: béppa

'cakes'

A: béppa pasa'é?

'cakes in the market?'

M: béppa anu, éé pada anu to? Panada sibawakué-kué bolu

'that cake, like that, isn't it? Panada and bolucakes(a type of traditional cakes)' 
A: hm. Oh, iya. Coco'ni palé'ko lo'ki'ménré di Boné to?

'hm. Oh yes. That's good anyway, since we [i.e. you] are going to Bone, aren't we [i.e. you]?'

M: iya

'yes'

A: idi'na ménré di Boné

'we [i.e. you] are going to Bone?'

M: Makkedai Puang Aji. Makkedai Puang Aji. Agi-agi ise'na lo' dielli? Ikotomma lo’melli

'Puang Aji said, Puang Aji said. Whatever you want to buy, since you are buying'

Aslinah's questions aga lo' taelli' 'what are we [i.e. you] going to buy?', a type of polite question. She used -ta, the first plural inclusive pronoun in taelli.Later, she used $-k i^{\prime}$ ' in $l o^{\prime} k i^{\prime \prime}$ we [i.e. you] are going to Bone'. In addition, she asks Minah if she is going to Bone using the first person inclusive pronoun as an address term, idi'na ménré'di Bone 'we [i.e. you] go to Bone'. This use of idi' is more polite than the equivalent (and also grammatically acceptable) ikona ménré' di Bone 'you go to Bone' would have been. Therefore, although the two are of similar age and status, the polite pronouns seem to have been influenced by the formality of the situation. In responding to the request, Minah repeats what their school headmaster (Puang Aji) had said, ikotomma lo' melli 'that is you who want to buy'. The second person pronoun $i k o$ is acceptable because of the status difference between the headmaster and the staff. Another example can be seen in the extract 4 below:

\section{Extract 4: The school evaluation}

Aslinah was arguing with her male colleague, Pak Mahmuddin (M, 35) who is older than she is, about the evaluation system in the school. Despite their similar status as teachers, the male speaker has higher status because of his noble background and his experience as a religious leader in Awangpone.

\section{A: di akhir evaluasi, itumi ujian praktek, yénaro..}

'at the end of evaluation, that is the practical test, that is..'

M: tapi...

'but...'

A: naidi' nappaki' makkukkuétalang soal

'but we [i.e. you] have just given a test now'

M: betul, betul to? Betul, tapi masalahnya, masalahnya kan, banyak ééé ada. Ada kurikulumnya itu yang belum kita selesaikan ini di akhir semester

'that is right, that is right, isn't it? that is right, but the problem, the problem is that, there are [many things], aren't they?. Umm..there is.. There is some curriculum material which has not been finished at the end of the semester'

Aslinah employs the distant pronouns $i d i^{\prime},-k i$, and $t a$ - to address Pak Mahmuddin in the last turn. This use was influenced by the setting as well as the differences in age, gender, and status between the interlocutors. Extract

$6,7,8$ below demonstrate the influences of those aspects in the way the female speaker, Puang Aji Masi (PAM, 50) to different interlocutors below:

\section{Extract 5: Asking a female fish seller}

PAM was talking to a female of similar age but different social status, Hunaeda (H, 50), a commoner without any hajj or noble status. Hunaeda was selling shrimps and prawns to PAM and other females: Puang Aji Semma (PAS, 50) and Puang Mari (PM, 50).

PAS: magi Hunaeda?

'what's the matter with it [i.e. you], Hunaeda?'

$\mathrm{H}$ : nulléna

'how can this be'

PAM: nulléna. Balaceng ibalu'

'how can this be? [We] sell shrimps'

$\mathrm{H}:$ lo ' $k i$ ' melliwi? 
'are we [i.e. you] going to buy some?'

PM: déto

'not really'

PAM: tassiawaé loppanutu?

'how much is a cup of those prawns of yours anyway?'

$\mathrm{H}$ : duwa sitengnga, $\underline{\text { Aji }}$

'two and a half [two thousand five hundred rupiahs], $A j i$ '

Although they are familiar as close neighbours, are of similar age and have been friends since a young age, the different status PAM has as hajj and noble encourages the non-reciprocal use of pronouns. PAM used the familiar possessive pronoun $-n u$ when she was asking about the price of the prawns, tassiawaé loppanutu? 'how much is a cup of those prawns of yours?'. Conversely, Hunaeda, a female commoner, used the distant pronoun $-k i$ ' in $l o$ ' $k i$ ' melliwi? 'are we [i.e. you] going to buy some?'. She also used polite address term $A j i$. This shows the asymmetrical relations among the interlocutors are influenced by their status differences.

\section{Extract 6: Asking an older fisherman}

PAM was talking to Mardi (M, 65), an older fisherman without any hajj or noble status. She was asking about Mardi's daily activities as a fisherman.

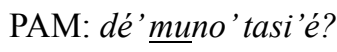

'didn't you go to the sea [fishing]?'

M: ba, polémuwa..'

'yes, I have been..'

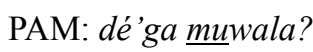

'didn't you catch anything [fish or any other seafood]?'

M: kamuwana..

'yes [there are] some but..'

PAM asked Mardi using the familiar pronoun $m u$ - in all of her questions above: dé' muno' tasi'é 'didn't you go to the sea [fishing]?' and dé'ga muwala? 'didn't you take anything [fish or any other seafood]?'. Like extract 5 above, this extract also shows an asymmetrical relation between the speakers influenced by their status differences. Although Mardi is older, and male, because of the high status of PAM, Mardi was addressed using the familiar pronoun. Compare this with extract 7 below:

\section{Extract 7: The mosque donation}

PAM was talking to an older male with high status since he is a hajj and noble, Puang Aji Akil (PAA, 64), who is also a close relative and neighbour. At the time, they were talking about the money owned by the mosque.

PAA: ko mabbicara makkeda iya' malamanengngi, tappa uti'maneng lao masigi'é

'if [someone] accused me of taking all [the money], then I would take [the money] directly to the mosque' PAM: iti' maneng lo'ka masigi'é?

'we [i.e. you] took all [the money] to the mosque, didn't we [i.e. you]?'

PAM used a polite device $i$ - in $\underline{i} t i$ ' instead of using $m u$ - in $\underline{m u t i}$ ' which would have been expressed in the utterance: muti' maneng lokka masigi'é. This extract shows the use of the first person plural inclusive agent marker as a generic marker, where no direct reference to a first person agent is entailed. It is used to refer to a second person agent, PAA, and it made her more distant and polite. This extract also shows that although both speakers are familiar, being close relatives and neighbours and have similar status as hajj and noble, pronoun choice is influenced by age and sex differences. Compare with extract 8 and 9 below:

\section{Extract 8: A female village head}

A female village head, Masliah (M, 37) was talking to Pak Camat 'Head of a sub-district', Haji Sudirman (HS, 53). HS was asking about the problem faced by her and she explained about the compulsory payment by each village head that had not been finalised.

HS: masalah aga? 
'what is the problem?'

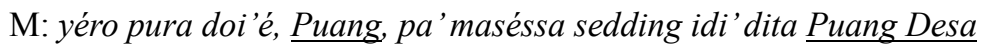

'that was the money, Puang, because it is difficult for us Puang Desa'

HS: purani?

'has it been [paid]?'

M: dépa Puang!

'not yet Puang!'

Masliah answered using the address term Puang, firstly because of the high position of HS as Pak Camat and secondly because he has noble and hajj status.

\section{Extract 9: Talking with a male village head}

Wahyuni (W, 36), a female with noble and good educational background had a chance to talk to Andi Luthfi (AL, $40)$, a male with noble status and a village head.

AL: Ilyas

'Ilyas'

W: magi Puang

'what's the matter with it, Puang?'

When asking a question to clarify who was visiting, Wahyuni used the address term Puang in magi Puang 'what's the matter with it, Puang?'. In the last turn, she also used the title Andi to refer to her relative: Andi Ilyas. This shows her respect although she herself has acquired similar noble status. This might be influenced by her gender.

\section{Extract 10: Asking about earrings}

Wahyuni (W, 36) was talking to Puang Aji Masi (PAM, 50) on the veranda about PAM's experience when she performed hajj. Ibu Wahyuni was asking about the earrings PAM had bought in Mecca which she was wearing at the time.

W: siyaga gerang yétu giwatta', Daéng?

'how many grams are your earrings, Daéng?'

PAM: duwa gerang aruwa kaca

'two grams and eight [carats]'

$\mathrm{W}$ : na duwa?

'for both? [for left and right earrings]'

PAM: iyé'

'yes'

$\mathrm{W}$ : gello’dita!

'they look nice!'

PAM: (trying to remember the price) masuli', siyagaro?

'[they are] expensive. How much are they?'

W: yakko'Afiah lo'ménré' matu', anu lo'wassuro melli

'if Afiah wants to go later [to perform hajj in Mecca], I want to ask [her] to buy [something]'

PAM: siyanu kennana yédé, lebbi telluratu'

'these are about three hundred thousand [rupiah]'

W: (asking me) ada kita beli?

'did you buy any [earrings]? [when you performed hajj]'

Both of them have high status as noble. To address PAM, who is her close relatives, Wahyuni used the intimate and polite address term, Daeng. Wahyuni also spoke Bugis to PAM. Speaking Indonesian will be considered inpolite in this case. However, when she addressed me, the researcher, she shifted into Indonesian. She asked me, 
ada kita beli? 'Did we [i.e. you] buy anything? [earrings]'. She chose Bugis-Indonesian since she knew my educational background as the researcher and my hajj status. The use of the Indonesian pronoun kita is a typical characteristic of Bugis speakers using Indonesian. Her code-switching is a way to show respect toward the educational and occupational status of the addressee. it is less polite to use other Indonesian pronouns such as kau/kamu.

Bugis speakers in the urban area also applied politeness strategies as influenced by the above aspects. This can be seen in the conversations of Haji Ros (HR, 42) below. HR to some extent has higher status as hajj and is senior in her teaching activities in Parepare as well as having a good educational background.

\section{Extract 11: A husband and a wife}

Haji Ros (HR, 42) and her husband, Aswar (A, 45) were talking at home. HR made a request to her husband, Aswar to accompany me to one of the schools. Her husband said that he did not need to accompany me because there was public transport there.

\section{HR: oh, Bacukiki itu dekat SMA 2, bagusmi kalau dari SMP 11 to, bawami}

'oh, Bacukiki is near SMA '[Sekolah Menengah Atas-Senior High School] 2', it is good if you go with her from SMP [Sekolah Menengah Pertama-Junior High School] 11'

\section{A: bisa dari cama'é, jalur pété-pétécama'é okkoro}

'[she] can [go there] from the district office, [because] that is the public transport route over there'

\section{HR: saya kira pereiko ji hari rabu}

'I thought you were free on Wednesday'

Hearing her husband's comment, HR said, saya kira pereiko ji hari rabu 'I thought you were free on Wednesday'. This implied that she wanted her husband to accompany me as she knew that her husband was free on that day. She showed her feeling of unease for her husband's reason through the use of a less polite pronoun- $k o$ in pereiko 'you were free'.

This extract shows that the different status can influence the level of politeness between husband and wife. HR' status as hajj and as a teacher influenced her level of politeness to her husband. This is different from the conversation between the husband and wife in extract 1 above, where a wife's politeness was not influenced by her educational status. The presence of other people — at the time I was there - did not encourage HR to be more polite either. The following extract also shows how familiar pronouns are used among mixed sex speakers:

\section{Extract 12: At the village office}

The male speaker, Mardi (M, 25) and the female speaker, Farida (F, 40) who are both staff in a village office in Parepare, were talking. Farida is senior to Mardi and she instructed Mardi to go massinge' 'asking for money which had been lent to the other people'. However, Mardi had a problem with transportation because the place is far away from their office.

\section{F: Kelurahan, nappa muti' la, lao mua'bagéang lao kuro}

'[you go to] the village office then, after that, you go and distribute this [invitation] there [another place]'

M: (explaining the problem) anunna transportasi

'the problem is the transportation'

F: dé, matu'pi na irita. Lokka jolo' massinge'. Iya' jolo' jokka nappa cina'pa ulokka singe'i tauwé. Ellinna bere'é

'no, we will see it later. Just go to collect the money first [from the debtor]. I wil also go there later to collect money from the people. The money from the rice sold!'

M: (explaining the problem again) dé', waseng transportasiélao kuro macawémi!

'no, I thought the transport to that place was nearby [but it wasn't]'

F: walakko anuééojekaa?

'I take you an ojek?'

Farida used the second person singular pronoun $m u$ - in her expressions: $\underline{m u t i}$ 'you take' and muabbagéang 'you distribute'. When Mardi was still concerned about the transport there, Farida then suggested taking an ojek 'a 
motorcycle taxi'. She also used the second person singular pronoun -koin walakko 'I take for you'. This extract shows that in formal settings, higher status woman may use familiar pronouns to lower status males.

\section{Extract 13: The school committee program}

Two older female teachers, Ida (I, 40) and Muna (M, 45) were asking a younger male teacher, Taking $(T, 28)$, to finish the work assigned to him. At the time, they were all members of the school committee.

\section{I: kan kita sibuk sekarang, bagaimana? Apakah selesai sekarang?}

'we [i.e. you] are busy at the moment, aren't you? how? Is it finished now?'

\section{M: hari Jumat matu'. Langsungmi éro Jumat}

'[you can finish it] later on Friday. Directly on Friday'

\section{T: hari Jumat éé..mungkin untuk..anu Pacéku tambah parah éé..iyé'}

'on Friday, umm..may be, for that one, my father's illness is worse, umm..yes'

M: oh begitu

'oh is it?'

I: (asking about the task for Taking) jadi bagaimana itu?

'so how is it?'

\section{M: karena sebentarji}

'because it will take only a minute'

\section{T: saya kembali hari minggu insya Allah kembali hari Minggu karena senin.}

'I will be back on Sunday. Hope God permit, I am back on Sunday because on Monday..'

Both the female teachers above requested Taking to finish his job soon. Taking could not make it, however, because his father (Pace) was sick. Later Taking agreed to do it on Monday. This shows that despite the fact that they are older than the male speaker, his gender and status may have influenced them to be more polite. The use of $m i$ 'just' as a softener in Langsungmiéro Jumat Directly on Friday'and $j i$ 'only', also as a softener, in karena sebentarii 'because it will take only a minute', served to soften their requests to the younger interlocutor.

Other extracts of conversations show the influence of familiarity and social status that can be seen in the following two extracts:

\section{Extract 14: Talking about jobs at home}

Suaeni (S, 35) was talking to Marwiah (27) at home about their jobs as teachers. They were newly met.

\section{A: jadi belumpaki' prajabatan?}

'So we [i.e. you] have not joined prajabatan?'

\section{W: belum}

'Not yet'

\section{A: oh, berarti bersamaangngi anu..itu temanku BP, duwa orang di sekolah, I anu namanya, I Aming}

' $\mathrm{Oh}$, it means she is the same as that one, that is my friend, BP [Bimbingan dan penyuluhan-Guidance and Counseling]. There are two people in the school [where she teaches]. His name is I Aming'

\section{W: oh kak éé..dimanaki' kak anu?}

'Oh, $k a k$, umm..where are we [i.e. you]? [teaching] kak?'

\section{A: di SMP 10}

'At SMP [Sekolah Menengah Pertama - Junior High School] 10'

Marwiah is a newly appointed teacher and has not undergone the compulsory training for teachers called prajabatan. Both of the speakers employ Bugis-Indonesian, recognized by the inclusion of the Bugis pronoun $-k i$ ' in some of the expressions. Suaeni's question, belumpaki' prajabatan 'so we [i.e. you] have not joined prajabatan?' for example, used $-k i$ '. She could have used the Indonesian pronouns kamu/kau, for example kamu belum prajabatan?, but this would have been less polite. Marwiah also used the polite device $-k i$ in her 
question, dimanaki' kak anu? 'where are we [i.e. you]?[teaching] kak?'. Compare this with extract 15 below, where she was talking to me as the researcher:

\section{Extract 15: A talk to the researcher}

\section{S: nukenalkah Ramlah?}

'do you know Ramlah?'

R: Ramlah siapa?

'Ramlah who?'

\section{S: Ramlah bahasa Inggris dulu, sembilan satu, yang biasa itu..terangkat..Samaka' dulu, mengajar dulu di Pinrang}

'Ramlah, the English department student, in the year of 91. She was appointed as a teacher in Pinrang with me'

\section{R: mungkin kukenal mukanya}

'probably I know her face'

\section{S: nakenalsekalikobédéng}

'she knows you very well anyway'

Suaeni and the researcher were known to each other before conducting research in Parepare. This meant she need not be so formal or polite despite the speakers' higher educational background. Suaeni asked in a familiar way using $n u$-, the second person pronoun,innukenalkah Ramlah? 'do you know Ramlah' and -koin nakenal sekalikobédéng'she knows you very much'. This shows that the choice of language can determine the level of politeness. Suaeni was using Indonesian with some Bugis pronouns ( $n u-,-k o,-k a$ and $n a-)$, however these pronouns were less polite and more familiar. To be more polite, she could have used kita 'we inclusive' and-ki'.

The above two extracts show that language choices either Bugis or Indonesian can indicate familiarity or unfamiliarity and level of politeness. Both extracts use Bugis-Indonesian, but extract 14 uses more polite devices than extract 15. Bugis pronouns, whether the most polite- $k i$ or the least polite- $k o$, were included in the speakers' Indonesian to mark their level of politeness.

\section{Discussion}

The results above show the important roles of social status, age, gender, familiarity, and situation in determining the level of politeness of Bugis people. Conversations of the female speaker, Aslinah, in extract 1, 2, 3, and 4 show the use of politeness strategies influenced by many different factors. In extract 1 , she used a familiar pronoun because she was familiar with her interlocutor: her younger brother. However, conversation at home with her husband in extract 2 led to the use of the more distant pronouns in order to be more polite, influenced by her status as a wife regardless of her high status as a teacher and a gradute from university and familiarity. In extract 3 and 4, her polite expressions were much influenced by setting. Situation in formal setting, that is in the school, led her to use more polite expressions.

Extract 5, 6, and 7 also demonstrate the important roles of social status differences among other aspects. When PAM, the female of noble status and hajj, was talking to commoners both with a female, Hunaeda and with a male, Mardi, she was using less polite expressions such as the pronoun $-m u$, regardless of age and gender differences. Different cases can be seen in extract 8 and 9, when Wahyuni and Masliah, two females of high status were talking to a male of high status. The extracts show that when talking to male of similar or higher status, women tend to be more polite. This indicates the important roles of sex differences among other aspects.

In urban area, Parepare, conversations in the extracts show different cases. In extract 11, for example, when a wife, Haji Ros was talking to her husband, she showed less polite expressions with the pronoun $-k o$. This is influenced by the hajj, educational, and occupation status of the Haji Ros, which is just similar to her husband. This is different in extract 2 in rural area, when Aslinah still used polite expressions to her husband although both of them acquire similar high status. Even in formal setting, women of high status still have a power to influence lower status and younger male in the conversations of extract 12 and 13.

Conversations of the informants with the researcher also show different politeness strategies. The presence of researcher with high educational, occupation, and also hajj status create different ways of being polite. In extract 10, for example, the speaker Wahyuni used different language to speak due to social status of her interlocutors. In extract 14 and 15 in which conversation took place among familiar and unfamiliar interlocutors, the speaker 
Suaeni demonstrated different expressions of politeness. She was using polite expression to her unfamilair interlocutor whereas to the researcher, who has been familiar with her, regardless of status differences, she just applied familiar ways of expressions which can be regarded less polite.

The extracts above show the interrelation of several factors in politeness expressions. The first one is about social status differences. In practice, noble status people are given more respect than other types of social status acquired from hajj, education, and occupation. Andi Mappasissi (70), an important adat leader in Awangpone, stated that ' $P a$ ' ya bawannatu pangka'é, ripasang lipa'mi, akku arung, asli' which means that 'Rank based on occupation is only worn like sarong, noble status is original'. Therefore, more respect should be given to the nobles because the title cannot be acquired easily like acquiring other titles. If they also have other higher status such as hajj or higher education or occupations, they will be respected even more.

The second factor is age differences.As noted by Millar (1983:479-480), Bugis society recognises 'a hierarchy determined by age' and in practice, this age difference influences the choices of being polite. Askar (28), a male informant in Parepare stated that politeness involves bagaimana cara menghargai orang yang lebih tua dari kita 'how to appreciate older people'. Older people confirm this idea and note that politeness between the older and younger generation should be mutually expressed as encapsulated in the Indonesian saying: yang muda menghargai yang tua, yang tua menyayangi yang muda 'the young respect the old, the old love the young'. Younger people are therefore expected to be polite to older people.

The notions on gender differences also influence how men and women in Bugis society should communicate to each other. Bugis men are expected to be warani 'brave' whereas Bugis women are expected to be malebbi' 'modest' (Idrus, 2003, 2005). Millar (1983:489) notes that for the Bugis, men need to behave 'aggressively and formally' whereas men need to behave 'cautiously and informally'.

Conversations in extract 1,2, 8, 9, 11, and 12 show the contribution of gender differences in being polite for the interlocutors. As we have seen in several extracts above, females are traditionally respectful towards males in Bugis society. However, when the females have higher status such as nobles and older, male speakers, especially commoners may show their high respect.Status differences become more important than gender differences.

Being familiar or not with one's interlocutors can influence the level of politeness of Bugis speakers. Marwiah (27), a female informant in Parepare illustrated the strong relationship between the level of familiarity and level of politeness. She told me that if they meet for the first time politeness is needed to be shown. This implies that if she is not familiar with her interlocutor, she will act more politely. She then becomes even more polite if she meets her interlocutor in a formal place, such as a school or office. Her conversation in extract 14 shows this preference.

Therefore, being a stranger or being familiar to someone will determine the ways of speaking. To maintain politeness one needs to be more distant or more familiar depending on this relationship. The more distant the interlocutors are, the more polite they are likely to talk. Conversely, the more familiar they are, the less polite they talk, marked by very familiar language and less polite expressions .Conversations in extract 14 and 15 demonstrate the roles of familiarity in expressing politeness.

Situation of the conversation contribute much to the politeness expressions of the interlocutors. This study also shows the important impact of the level of formality of a situation on Bugis politeness. Formal situation may lead to more polite interactions than informal situations. In this way, people may act and speak in a more formal way when they speak with their colleagues in an office or school than they would outside. Bugis speakers also to the informality and formality of the situation through choice of dress, the language spoken, and the type of activity conducted.

Several extracts above demonstrate that situation in the formal and informal settings of the conversation can determine the polite and less polite expressions used by speakers. The main difference can be seen from the rural and urban settings, in which female speakers in rural area are influenced much by their social status whereas in urban settings, gender differences play important roles. Conversations of housewife in rural and urban area as can be seen in extract 2 and 11 show differences in polite expressions which is also influenced by differences in social status and gender differences.

This discussion shows that being polite or not should be put in many different contexts. There are many factors influencing people to be polite as Brown and Levinson (1987) put those factors such as power, distance, and rank of imposition whereas according to Holmes (1995), there are three dimensions which have proved useful in analysing linguistic politeness, namely 'solidarity-social distance dimension', the 'power dimension', and the 'formality dimension'. 
This discussion also shows that different types of polite expressions have been used by speakers above with different interlocutors. The most important polite markers are pronouns, address terms, and discourse markers such as $m i$ and $j i$ as softeners (Mahmud, 2008a, 2010, 2011). It is usually more polite to use the first person plural inclusive forms (idi',-ki',ta-/i-) rather than the plain second person forms ( $i k o,-k o, n u-/ m u-)$. The use of the pronouns are based on social status, which is in line with the use of pronouns of 'power and solidarity' as proposed by Brown and Gilman (1972:255-277). Address terms can also mark their politeness when talking to certain interlocutor such as the use of Puang for the noble status people. In addition, language choices whether Bugis or Indonesian becomes an alternative to be more polite or less polite (Mahmud, 2008b). These polite markers are commonly known as 'honorification' (Agha, 1994), and have been used as polite markers in many different society, such as in Java (Geertz, 1960, Errington, 1998).

\section{Conclusion}

This paper has discussed the different ways of practising politeness by Bugis people influenced by different aspects.The first and the most important one is social status, arising from the hierarchical system of Bugis society. Other important aspects influencing Bugis politeness are age differences, gender, familiarity, and situation. The discussion also shows some strategies used by Bugis people to encode their politeness, such as the use of pronouns, address terms, and language choices either Bugis or Indonesian.

\section{Acknowledgement}

I would like to thank to my panel supervisors at the Australian National University, Prof. Kathryn Robinson, Dr. John Bowden, and Prof. Emeritus. Campbell Macknight for their assistance in my Ph. D.

\section{References}

Abdullah, H. (1985). Manusia Bugis Makassar: Suatu tinjauan historis terhadap pola tingkah laku dan pandangan hidup manusia Bugis Makassar. Jakarta: Inti Idayu Press.

Agha, A. (1994). Honorification. Annual Review of Anthropology, 23, 277-302. http://dx.doi.org/10.1146/annurev.an.23.100194.001425

Alimi, M. Y. (2012). Head covering to live by: Cipo'-cipo', Shari'ah, and women's experince of clothing in South Sulawesi. Intersections: Gender and Sexuality in Asia and the Pacific, (30).

Bacha, N. N., Bahous, R., \& Diab, R. L. (2012). Gender and politeness in a foregin language academic context. International Journal of English Linguistics, 2(1), 79-96. http://dx.doi.org/10.5539/ijel.v2n1p79

Berman, L. (1998). Speaking through the silence: narrative, social conventions, and power in Java. New York, Oxford: Oxford University Press.

Bonvillain, N. (1993). Language, culture, and communication: the meaning of messages. Englewood Cliffs: Prentice Hall.

Brawn, D. M. (1993). Immanent domains: Ways of living in Bone, Indonesia. Ph.D Thesis. Anthropology Department, Michigan: the University of Michigan.

Brown, P., \& Levinson, S. (1987). Politeness: Some universals in language use. Cambridge, New York: Cambridge University Press.

Brown, R., \& Gilman, A. (1972). The pronouns of power and solidarity. In P. P. Giglioli (Ed.), Language and social context (pp. 252-282). Great Britain: Cox \& Wyman Ltd, Reading.

Buchori, M. (1994). Sketches of Indonesian society: A look from within. Jakarta: IKIP Muhammadiyah Jakarta-Press and TheJakarta Post.

Du Bois, J. W., Schuetze-Coburn, S., Cuming, S., \& Paolino, D. (1993). Outline of Discourse Transcription. In J. A. Edwards, \& M. D. Lampert (Eds.), Talking Data: Transcription and Coding in Discourse Research (pp. 45-90). New Jersey, Hillsdale: Lawrence Erlbarn Associates, Publishers.

Errington, J. J. (1985). Language and social change in Java: Linguistic reflexes of modernization in a traditional royal polity. Ohio, USA: Center for International Studies, Ohio University.

Errington, J. J. (1986). Continuity and Change in Indonesian Language Development. The Journal of Asian Studies, 45(2), 329-353. http://dx.doi.org/10.2307/2055846

Errington, J. J. (1988). Structure and style in Javanese: A semiotic view of linguistic etiquette. Philadelphia: University of Pennsylvania Press.

Errington, J. J. (1998). Shifting languages: Interaction and identity in Javanese Indonesian. UK: Cambridge 
University Press. http://dx.doi.org/10.1017/CBO9780511612480

Geertz, C. (1960). The religion of Java. Illinois: The Free Press of Glencoe.

Gerth, H. H., \& Mills, C. W. (Eds.). (1976). From Max Weber: Essays in Sociology. New York: Oxford University Press.

Graham, S. (2001). Negotiating gender: Calalai' in Bugis Society. Murdoch University. Retrieved March 11, 2004, from http://wwwsshe.murdoch.edu.au/intersections/issue6/graham.html

Graham, S. L. (2007). Disagreeing to Agree: Conflict, (Im)politeness and Identity in a Computer-Mediated Community. Journal of Pragmatics, 39, 742-759. http://dx.doi.org/10.1016/j.pragma.2006.11.017

Gu, Y. (1990). Politeness phenomena in modern Chinese. Journal of Pragmatics, 14, 237-257. http://dx.doi.org/10.1016/0378-2166(90)90082-O

Hobbs, P. (2003). The medium is the message: Politeness strategies in men's and women's voice mail messages. Journal of Pragmatics, 35, 243-262. http://dx.doi.org/10.1016/S0378-2166(02)00100-5

Holmes, J. (1995). Women, men, and politeness. London and New York: Longman.

Hung, S., \& Bradac, J. J. (1993). Power in language: Verbal communication and social influence. London: Sage Publications: International Educational and Professional Publisher.

Idrus, N. I. (2003). To take each other: Bugis practice of gender, sexuality, and marriage. Ph.D Thesis. Canberra: Research School of Pacific and Asian Studies. Australian National University.

Idrus, N. I. (2005). Siri', gender, and sexuality among the Bugis in South Sulawesi. Antropologi Indonesia, 29(1).

Idrus, N. I. (2011). State regulatios, Islam, and local practice of marriage among the Bugis in South Sulawesi. In Gavin et al. (Eds.), Changing marriage patterns in Southeast Asia: Economic and Socio-cultural dimensions. London: Routledge.

Intachara, S. (2011). Politeness motivated by 'the heart' and 'the binary rationality' in Thai culture. Journal of Pragmatics, 44, 619-635. http://dx.doi.org/10.1016/j.pragma.2011.07.016

Kakane, I. (2008). Politeness and gender in interpreted police interviews. Monash University Linguistics Papers, $6(1), 29-40$.

Kartomiharjo, S. (1981). Ethnography of communicative codes in East Java. Ph.D Thesis. Canberra: Research School of Pacific and Asian Studies, the Australian National University.

Kummer, M. (1992).Politeness in Thai. In R. J. Watts, S. Ide, \& Konrad Ehlich (Eds.), Politeness in language: Studies in its history, theory, and practice (pp. 326-336). New York: Mouton de Gruyter.

Mahmud, M. (2008a). Politeness in Bugis. A Ph.D Thesis. Canberra, Australia: The Australian National University.

Mahmud, M. (2008b). Speaking Bugis and Speaking Indonesian in Bugis Society. Review of Indonesia and Malay Affairs, 42(2), 67-92.

Mahmud, M. (2010). Grammatical expressions of Bugis politeness. Lingua, Jurnal Ilmu Bahasa dan Sastra, 5(1), 84-91.

Mahmud, M. (2011). Pronoun choices in Bugis society: The road to encode politeness. Humaniora, Journal of Culture, Literature, and Linguistics, 23(2), 209-218.

Mahyuni. (2003). Speech styles and cultural perspectives in Sasak community. Ph.D Thesis. Melbourne, Australia: University of Melbourne.

Millar, S. (1983). On Interpreting Gender in Bugis Society. American Ethnologist, 10(3), 477-493. http://dx.doi.org/10.1525/ae.1983.10.3.02a00050

Millar, S. (1989). Bugis Weddings: Rituals of Social Location in Modern Indonesia. Berkeley: Center for South and Southeast Asia Studies, University of California.

Mizutani, O., \& Mizutani, N. (1987). How to be polite in Japanese. Tokyo, Japan: The Japan Times, Ltd.

Ossowski, S. (1963). Class structure in the social consciousness. London: Routledge and Kegan Paul.

Pelras, C. (1996). The Bugis. Cambridge, Massachussets: Blackwell Publishers.

Pizziconi, B. (2003). Re-examining Politeness, Face, and the Japanese Language. Journal of Pragmatics, 35 , 
1471-1506. http://dx.doi.org/10.1016/S0378-2166(02)00200-X

Shibamato-Smith, J. S. (2011). Honorifics, "politeness", and power in Japanese political debate. Journal of Pragmatics, 43, 3707-3719. http://dx.doi.org/10.1016/j.pragma.2011.09.003

Speer, S. A. (2002). Sexist Talk: gender Categories, Participant' Orientations and Irony. Journal of Sociolinguistics, 6(3), 347-377. http://dx.doi.org/10.1111/1467-9481.00192

Turner, B. S. (1988). Status. Milton Keynes: Open University Press.

Wouk, F. (2001). Solidarity in Indonesian Conversation: The Discourse Marker ya. Journal of Pragmatics, 33, 171-191. http://dx.doi.org/10.1016/S0378-2166(99)00139-3

Zhan, K. (1992). The Strategies of politeness in the Chinese language. California, USA: The Regents of the University of California.

\section{Notes}

Note 1. The different languages used by the Bugis people are identified using different fonts in the extracts taken as examples: Times New Romanfor the Bugis and Comic Sans MS for Indonesian. Both are represented in italics.

Note 2. I use initials for names of speakers mentioned for the first time followed by the age, such Puang Aji Madi (PAM, 50) or Wahyuni (W, 36).

Note 3. Some symbols for transcriptions used for conversations are as follows:

- Final intonation contour (usually a low falling pitch).

, Continuing intonation contour (level, or slight rise).

? Appeal intonation contour (sharp rise in pitch).

- Truncated word.

(a) One pulse of laughter.

..Short pause (less than roughly 0.8 seconds)

...Long pause (longer than roughly 0.8 seconds)

$<@$ words@ $>$ Words are spoken while laughing; can also be written@word @word @word.

(text) explaining what the conversation/the turn is about

[text] giving the literal meaning of the conversation

(text)

(text) indicating interjections (adpted from (adapted from Du Bois et al, 1993: 45-90) 